\title{
KEANEKARAGAMAN PARASITOID DAN ARTROPODA PREDATOR PADA PERTANAMAN KELAPA SAWIT DAN PADI SAWAH DI CINDALI, KABUPATEN BOGOR
}

\author{
Herni Dwinta Pebrianti ${ }^{1}$, Nina Maryana ${ }^{2}$, \& I Wayan Winasa ${ }^{2}$ \\ ${ }^{1}$ Mahasiswa Pascasarjana Entomologi, Institut Pertanian Bogor \\ ${ }^{2}$ Departemen Proteksi Tanaman, Fakultas Pertanian, Institut Pertanian Bogor \\ Jl. Kamper Kampus IPB Dramaga, Bogor 16680 \\ E-mail: hernidp13@gmail.com
}

\begin{abstract}
Diversity of parasitoid and predator arthropod in oil palm and paddy field at Cindali, Bogor Regency. Biodiversity can be defined as the diversity of living things in various places to the riches on earth. Insects as one of the components of biodiversity have an important role in the food web as herbivores, carnivores (parasitoids and predators), and detritivores. The research aimed to study the diversity of parasitoids and predators at two sampling locations. Sampling was carried out at the oil palm plantation PTPN VIII Cindali, Ranca Bungur, Bogor and at the paddy fields that adjacent to the plantation. This research was conducted in December 2014 until July 2015. This research takes 3 plots in oil palm plantations and 3 plots in paddy field. Each plot consists of 5 subplots, one of each was $18 \times 18 \mathrm{~m}$. Sampling was carried out following the paddy age, since 2 week after plantation until paddy harvested and repeated every 2 weeks. This research use three methods, i.e. insect nets, pitfall trap and yellow pan trap. The results showed that the diversity of parasitoids and predators on both planting locations was high. In the oil palm plantations the total number of insect parasitoids and predators was 184 morphospecies from 10 orders and 57 families, while in the paddy fields was 183 morphospecies from 10 orders and 60 families. Telenomus podisi parasitoids and predators Anoplolepis gracilipes is morphospecies with the highest abundance.
\end{abstract}

Key words: ground vegetation, insect trap, natural enemies

\begin{abstract}
ABSTRAK
Keanekaragaman parasitoid dan artropoda predator pada pertanaman kelapa sawit dan padi sawah di Cindali, Kabupaten Bogor. Keanekaragaman hayati dapat diartikan sebagai keanekaragaman makhluk hidup di berbagai tempat yang menjadi kekayaan di muka bumi. Serangga sebagai salah satu komponen keanekaragaman hayati memiliki peranan penting dalam jaring makanan yaitu sebagai herbivora, karnivora (parasitoid dan predator) dan detritivora. Penelitian bertujuan untuk mengetahui keanekaragaman parasitoid dan predator pada pertanaman kelapa sawit dan area persawahan di Cindali, Bogor. Pengambilan sampel dilaksanakan pada perkebunan kelapa sawit PTPN VIII Cindali, Ranca Bungur, Bogor dan pertanaman padi sawah yang berdekatan dengan perkebunan tersebut. Pengamatan dilakukan pada bulan Desember 2014 - Juli 2015. Penelitian ini mengambil 3 plot pada tanaman kelapa sawit dan 3 plot pada padi sawah. Setiap plot terdiri dari 5 subplot, satu subplot berukuran $18 \mathrm{~m}$ x $18 \mathrm{~m}$. Pengambilan sampel mengikuti umur padi yaitu, sejak padi berumur 2 MST hingga menjelang padi dipanen, diulang setiap 2 minggu sekali dengan menggunakan 3 metode, yaitu jaring serangga, perangkap lubang, dan perangkap nampan kuning. Hasil penelitian menunjukkan keanekaragaman parasitoid dan predator pada kedua lokasi pertanaman tinggi. Pada pertanaman kelapa sawit individu serangga parasitoid dan predator berjumlah 184 morfospesies dari 10 ordo dan 57 famili, sedangkan padi sawah diperoleh 183 morfospesies dari 10 ordo dan 60 famili. Parasitoid Telenomus podisi dan predator Anoplolepis gracilipes merupakan morfospesies dengan kelimpahan tertinggi.
\end{abstract}

Kata kunci: musuh alami, perangkap serangga, vegetasi bawah

\section{PENDAHULUAN}

Keanekaragaman hayati dapat diartikan sebagai keanekaragaman makhluk hidup di berbagai tempat yang menjadi kekayaan di muka bumi. Menurut Yaherwandi
(2005), Indonesia adalah negara tropis sehingga kaya akan keanekaragaman hayati tersebut, baik flora maupun fauna. Buchori (2014) menyatakan bahwa Indonesia adalah negara yang kaya akan keanekaragaman hayati dan telah diakui dunia sebagai 
salah satu negara mega biodiversity, salah satunya adalah serangga. Keanekaragaman serangga pada suatu habitat berbeda, karena faktor tanaman, keadaan iklim, dan keadaan habitat di sekitar (Rizali et al., 2002). Keberadaan hutan sebagai habitat alami menyediakan jumlah serangga karnivora lebih banyak dan keanekaragaman serangga lebih tinggi dan kompleks dibandingkan dengan agroekosistem (Janzen, 1987).

Menurut LaSalle (1993), parasitoid merupakan musuh alami yang penting pada kebanyakan hama tanaman dan bertindak sebagai spesies kunci pada beberapa ekosistem. Parasitoid mampu mengendalikan hama secara spesifik dan populasinya di lapangan relatif cukup tinggi (Godfray, 1994). Predator merupakan pemangsa organisme lain yang hidup bebas di alam untuk memenuhi kebutuhan hidup dan dapat menyerang mulai dari fase pradewasa sampai dengan fase dewasa. Predator membutuhkan beberapa mangsa selama hidupnya sehingga dapat dimanfaatkan dalam menekan jumlah populasi hama di lapangan.

Tanaman kelapa sawit dan padi sawah merupakan tanaman yang dibudidayakan secara monokultur. Praktik pertanian, baik tanaman tahunan maupun semusim tidak terlepas dari pengaruh keanekaragaman hayati terhadap kuantitas dan kualitas produk yang dihasilkan (Pradhana et al., 2014). Keanekaragaman hayati dalam hal ini adalah keanekaragaman serangga di suatu habitat yang dipengaruhi oleh lingkungan di sekitarnya dan vegetasi yang tumbuh di dalamnya. Menurut Rohrig et al. (2008), tumbuhan dapat menyediakan nektar bunga yang dapat meningkatkan daya hidup dan keperidian serangga. Pada suatu habitat, keberadaan tumbuhan sangat beragam jenis dan komposisinya, termasuk pada pertanaman kelapa sawit dan padi sawah. Hal ini akan menciptakan perbedaan keanekaragaman serangga karnivora (parasitoid dan predator) yang tinggal di dalamnya.

PT Perkebunan Nusantara (PTPN) VIII Afdeling 1 Cindali, Kecamatan Ranca Bungur, Kabupaten Bogor merupakan salah satu lokasi pertanaman kelapa sawit di Jawa Barat, selain itu terdapat juga pertanaman padi sawah yang berdekatan dengan tanaman kelapa sawit. Berdasarkan kondisi ini menarik untuk dilihat perbedaan keanekaragaman serangga parasitoid dan predator pada kedua pertanaman tersebut, hal ini dapat dilakukan dengan mengambil imago serangga di lapangan sebanyak mungkin untuk melihat keanekaragaman dan kelimpahannya. Penelitian ini bertujuan untuk mengetahui keanekaragaman dan kelimpahan artropoda parasitoid dan predator pada pertanaman kelapa sawit dan padi sawah di Cindali Kecamatan Ranca Bungur, Kabupaten Bogor.

\section{METODE PENELITIAN}

Tempat dan Waktu. Penelitian dilaksanakan pada dua pertanaman, yaitu pertanaman kelapa sawit PTPN VIII Afdeling 1 Cindali dan pertanaman padi sawah yang berada berdekatan dengan tanaman kelapa sawit. Kedua lokasi berada di Kecamatan Ranca Bungur, Kabupaten Bogor. Sortasi dan identifikasi dilaksanakan di Laboratorium Biosistematika Serangga, Departemen Proktesi Tanaman, Fakultas Pertanian, Institut Pertanian Bogor. Penelitian dilaksanakan pada bulan Desember 2014 sampai dengan Juli 2015.

Metode Pengambilan Sampel. Pengambilan sampel serangga dilakukan pada 2 lokasi pertanaman. Setiap lokasi penelitian terdiri atas 3 plot, sehingga total adalah 6 plot. Pemilihan plot pada kelapa sawit dilakukan secara acak pada beberapa blok yang memiliki luas sekitar 145 - 150 ha dan berdekatan dengan sawah. Pemilihan plot pada padi sawah dilakukan dengan mengambil 3 lahan sawah yang kepemilikannya berbeda namun umur padinya sama dan memiliki luas sekitar $4000-5000 \mathrm{~m}^{2}$. Pada setiap plot kelapa sawit dan padi sawah ditentukan 5 subplot. Satu subplot berukuran 18 $\mathrm{x} 18 \mathrm{~m}$.

Pengambilan sampel parasitoid dan predator pada 2 lokasi pertanaman dilakukan mengikuti umur padi yaitu sejak padi berumur 2 minggu setelah tanam (MST) hingga menjelang padi dipanen, dan diulang setiap 2 minggu sekali. Pengambilan sampel dilakukan dengan 3 metode, yaitu menggunakan jaring serangga, perangkap lubang dan perangkap nampan kuning.

Metode Jaring Serangga. Pengambilan sampel dilakukan dengan mengayunkan jaring serangga sebanyak 100 kali ayunan ganda pada setiap subplot, sehingga total setiap plot yaitu 500 kali ayunan ganda. Satu kali ayunan ganda adalah mengayunkan jaring serangga 1 kali ke kiri dan 1 kali ke kanan. Jaring serangga yang digunakan berdiameter $30 \mathrm{~cm}$ dengan panjang tongkat $80 \mathrm{~cm}$, dan jaring tersebut terbuat dari kain organdi. Hasil dari jaring serangga dimasukkan ke dalam separator yang berukuran $26,5 \mathrm{~cm}$ untuk sisi samping, $17,5 \mathrm{~cm}$ sisi depan, $16 \mathrm{~cm}$ sisi belakang, $18 \mathrm{~cm}$ lebar sisi depan dan $16,5 \mathrm{~cm}$ lebar sisi belakang. Separator diberi botol plastik yang berisi alkohol $70 \%$ sebagai wadah tempat sampel.

Metode Perangkap Lubang. Perangkap lubang berupa wadah plastik bening dengan volume $\pm 240 \mathrm{ml}$, berdiameter $7 \mathrm{~cm}$ dan tinggi wadah $10 \mathrm{~cm}$ yang dipasang dengan cara permukaannya rata dengan permukaan 
tanah di sekitarnya. Perangkap lubang diisi dengan larutan gliserol sebanyak seperempat dari tinggi wadah. Pada setiap plot dipasang 10 perangkap atau pada setiap subplot terdapat 2 perangkap yang dipasang selama $2 \mathrm{x}$ 24 jam. Pada lokasi pertanaman padi sawah, pemasangan dilakukan di pematang sawah yang dipasang pada pinggir petak pengamatan.

Metode Perangkap Nampan Kuning. Perangkap terbuat dari wadah plastik kuning berukuran $22 \times 14 \times 4$ $\mathrm{cm}$ diisi larutan sabun sebanyak setengah dari wadahnya dan diletakkan pada permukaan tanah. Pada setiap plot dipasang 10 perangkap, 2 perangkap per subplot selama $1 \times 24$ jam.

Pengamatan Vegetasi Bawah. Pengamatan vegetasi bawah dilakukan dengan tujuan sebagai data pendukung dalam penelitian. Vegetasi yang ditemukan dalam plot pengambilan sampel dicatat, diambil dan dibuat herbarium untuk selanjutnya diidentifikasi hingga tingkat spesies.

Identifikasi Sampel. Sampel diidentifikasi sampai ke tingkat morfospesies. Identifikasi serangga dilakukan dengan acuan beberapa kunci identifikasi (Grissel \& Schauff, 1990; CSIRO, 1991; Goulet \& Huber 1993; Borror et al., 1996; Triplehorn \& Johnson, 2005) serta dengan menggunakan spesimen referensi dari berbagai sumber.

Analisis Data. Data hasil identifikasi ditabulasikan dalam satu tabel pada perangkat lunak Microsoft Excel. Analisis data dilakukan dengan penghitungan indeks keanekaragaman Shannon-Wiener (Nolan \& Callahan,
2005). Data dianalisis menggunakan program $R$ Statistic versi 3.0.2.

\section{HASIL DAN PEMBAHASAN}

Keanekaragaman dan Kelimpahan Parasitoid dan

Predator. Parasitoid dan predator yang diperoleh dalam penelitian ini berjumlah 228 morfospesies yang diperoleh dari 11 ordo dan 69 famili (Tabel 1). Keanekaragaman parasitoid dan predator yang diperoleh lebih tinggi pada pertanaman kelapa sawit dibandingkan dengan pertanaman padi sawah. Beragamnya parasitoid dan predator yang ditemukan pada area kelapa sawit diduga karena terdapat banyak vegetasi bawah yang dapat mendukung kelangsungan hidup dari musuh alami. Apabila dibandingkan vegetasi bawah antara pertanaman kelapa sawit dengan area persawahan, maka pada pertanaman kelapa sawit terdiri atas 18 ordo, 25 famili, dan 42 morfospesies; sedangkan pada area persawahan terdapat 11 ordo, 13 famili, dan 17 morfospesies. Menurut Barbosa \& Benrey (1998), semakin banyak dan beragam spesies tumbuhan yang terdapat dalam suatu habitat, maka semakin tinggi keanekaragaman musuh alami pada habitat tersebut.

Fungsi serangga sebagai parasitoid dan predator pada kedua lokasi pertanaman masing-masing menunjukkan keanekaragaman yang tinggi, karena memiliki nilai indeks keanekaragaman lebih dari 3 (Tabel 2). Hal ini salah satunya dikarenakan banyaknya jenis vegetasi bawah yang berada pada pertanaman kelapa sawit dan padi sawah yang merupakan tempat hidup dan sumber makanan bagi parasitoid dan predator. Siemann et al. (1999) menyatakan bahwa keanekaragaman predator dan parasitoid tergantung

Tabel 1. Parasitoid dan predator pada lokasi pertanaman kelapa sawit dan pertanaman padi sawah

\begin{tabular}{lcccc}
\hline \multirow{2}{*}{ Lokasi } & \multicolumn{4}{c}{ Jumlah } \\
\cline { 2 - 5 } & Ordo & Famili & Morfospesies & Individu \\
\hline Pertanaman kelapa sawit & 2 & 25 & 101 & 3,248 \\
$\quad$ Parasitoid & 10 & 32 & 83 & 7,587 \\
Predator & 10 & 57 & 184 & 10,835 \\
\hline Total & 3 & & 95 & 1,910 \\
\hline Pertanaman padi sawah & 9 & 27 & 88 & 5,731 \\
$\quad$ Parasitoid & 10 & 63 & 183 & 7,641 \\
$\quad$ Predator & & & &
\end{tabular}


pada keanekaragaman herbivora, selain itu tergantung juga pada keanekaragaman tanaman.

Selain itu, umur kelapa sawit juga dapat memengaruhi keanekaragaman parasitoid dan predator pada suatu habitat. Semakin tua umur kelapa sawit, maka akan memengaruhi kondisi vegetasi yang terdapat di dalamnya. Menurut Luskins \& Potts (2011), umur tanaman sawit yang lebih tua memengaruhi banyaknya vegetasi bawah yang tumbuh pada sawit tersebut.

Selain vegetasi bawah, keanekaragaman serangga lain juga memengaruhi keanekaragaman parasitoid dan predator yang ada. Serangga lain merupakan inang bagi parasitoid dan mangsa bagi predator. Semakin tinggi keanekaragaman serangga lain yang ada pada suatu habitat, maka dapat dimungkinkan semakin tinggi juga keanekaragaman parasitoid dan predator yang terdapat pada habitat tersebut. Hal ini berkaitan dengan terpenuhi dan tercukupinya makanan bagi parasitoid dan predator tersebut. Menurut Sahari (2012), keanekaragaman parasitoid selalu mengikuti keanekaragaman inang yang umumnya serangga fitofag, keanekaragaman serangga fitofag bergantung terhadap ketersedian tanaman inang di ekosistem.

Hal ini juga didukung dengan perhitungan nilai indeks Shanon-Wienner yang memiliki nilai lebih dari 3. Nilai indeks Shanon-Wienner yang diperoleh adalah 3,49. Hal ini membuktikan bahwa tingkat keanekaragaman parasitoid dan predator pada kedua lokasi pertanaman memiliki tingkat keanekaragaman yang tinggi.

\section{Dominansi Artropoda Parasitoid dan Predator.} Total morfospesies dari parasitoid dan predator adalah 228 morfospesies, dengan jumlah tertinggi dari kelompok parasitoid pada kedua pertanaman sebanyak 120 morfospesies. Hal ini karena parasitoid mempunyai karakteristik antara lain jumlah populasi di lapangan yang melimpah dengan inang spesifik berupa serangga (Godfray, 1994). Parasitoid mempunyai kemampuan beradaptasi yang baik dengan lingkungan, memiliki kebutuhan makanan per individu yang rendah dan memiliki kemampuan untuk mencari inang yang tinggi.

Tiga ordo serangga yang berperan sebagai parasitoid, yaitu Ordo Diptera, Hymenoptera, dan Strepsiptera (Gambar 1). Dominansi kelimpahan dan jumlah morfospesies parasitoid tertinggi berasal dari ordo Hymenoptera, baik pada pertanaman kelapa sawit maupun padi sawah dengan masing-masing berjumlah 3201 dan 1856 individu. Hal ini didukung dengan pendapat Hassel \& Waage (1984) bahwa keanekaragaman parasitoid yang tinggi terdapat pada ordo Hymenoptera dengan kurang lebih 200000 spesies.
Individu parasitoid yang dominan ditemukan pada Ordo Hymenoptera tersebut terdapat pada Famili Braconidae, Scelionidae dan Eulophidae. Tingginya perolehan diduga karena penyebaran famili ini yang cukup merata dan menempati beragam habitat.

Sembilan ordo serangga dan satu ordo laba-laba yang berperan sebagai predator ditemukan pada lokasi pertanaman kelapa sawit dan padi sawah (Gambar 1). Artropoda predator yang banyak ditemukan adalah dari Ordo Hymenoptera dan Araneae pada kelapa sawit, serta Ordo Diptera dan Araneae pada padi sawah. Individu predator yang dominan ditemukan pada Ordo Hymenoptera adalah Famili Formicidae, Ordo Araneae adalah Famili Oxyopidae dan Ordo Diptera terdapat pada Ceratopogonidae.

Hymenoptera yang paling banyak ditemukan yaitu dari Famili Formicidae, hal ini karena banyaknya vegetasi bawah dan lingkungan pada habitat perkebunan kelapa sawit yang memiliki kondisi yang lembab. Menurut Atkins (1980), anggota Famili Formicidae banyak ditemukan pada daerah yang memiliki keadaan lembab dan pada daerah-daerah di sekitar hutan hujan tropis. Ordo Araneae ditemukan dengan jumlah yang cukup banyak pada kedua lokasi pertanaman. Ordo Araneae merupakan salah satu kelompok yang dominan pada ekosistem pertanian pada umumnya dan berperan penting dalam ekosistem sawah, serta berperan dalam menekan populasi hama padi (Herlinda et al., 2008). Ordo Diptera yang ditemukan dengan jumlah yang banyak adalah dari Famili Ceratopogonidae. Banyaknya Diptera pada habitat persawahan karena persawahan merupakan lahan basah, dan kebanyakan larva yang ditemukan pada perairan adalah anggota dari Ordo Diptera (Daly et al., 1978).

Morfospesies parasitoid dengan jumlah individu paling banyak adalah Telenomus podisi, karena parasitoid ini merupakan parasitoid telur dari Famili Scelionidae dan memiliki sifat yang polifagus (Tabel 2). Menurut Goulet \& Huber (1993), Famili Scelionidae merupakan parasitoid telur dari banyak serangga sehingga memiliki jumlah spesies yang banyak. Predator yang paling banyak ditemukan adalah Anoplolepis gracilipes yang dikenal sebagai yellow crazy ants yang merupakan spesies invasif. Melimpahnya A. gracilipes diduga karena memiliki mangsa yang sangat luas. Dominansi morfospesies ini berdasarkan jumlah individu tertinggi yang ditemukan.

Pada kedua lokasi pertanaman, beberapa parasitoid dan predator hanya ditemukan pada pertanaman kelapa sawit maupun sebaliknya hanya ditemukan pada pertanaman padi sawah. Namun dari hasil penelitian juga didapatkan parasitoid dan predator 
A

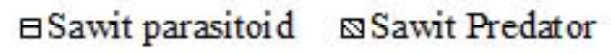

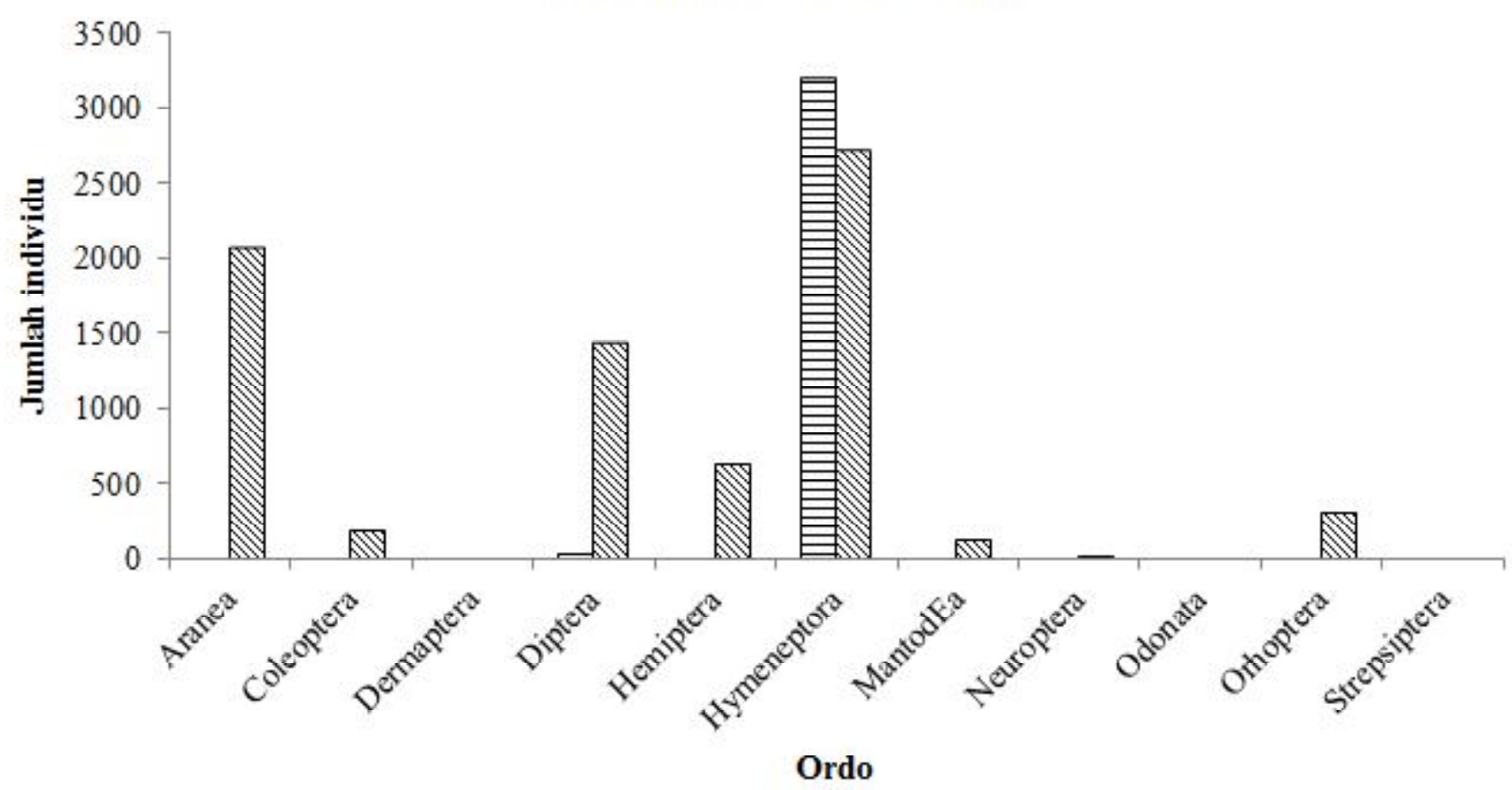

B घSawah parasitoid घSawah Predator

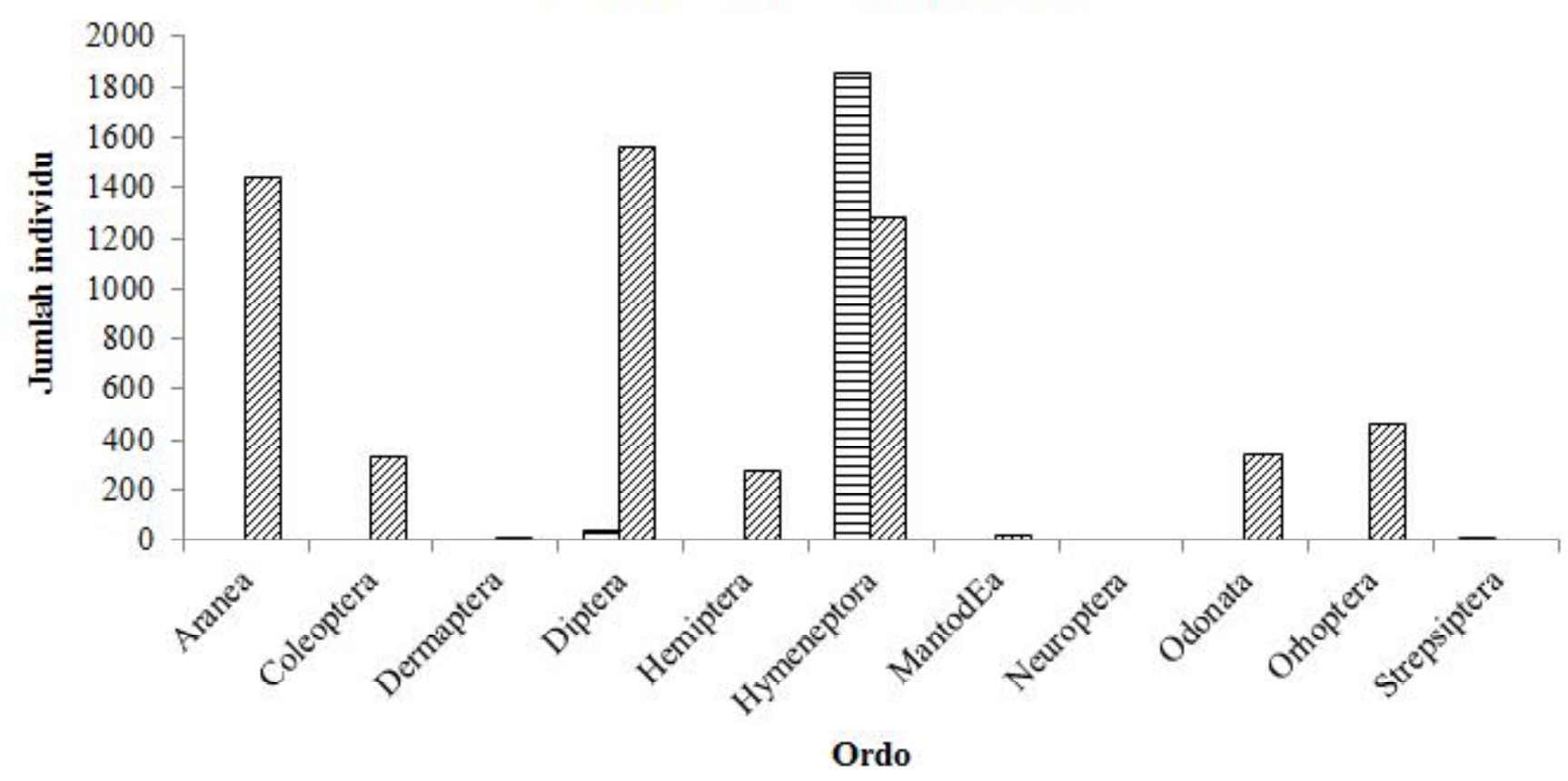

Gambar 1. Kelimpahan individu artropoda parasitoid dan predator pada pertanaman (A) kelapa sawit dan (B) padi sawah

yang sama-sama ditemukan pada dua lokasi tersebut (Gambar 2). Hal ini menunjukkan bahwa terdapat pengaruh yang positif dari letak lokasi pertanaman yang berdekatan. Berdasarkan penelitian Rizali et al. (2002), bahwa lahan pertanian padi yang terletak berdekatan dengan tepian hutan memiliki nilai kesamaan komposisi spesies yang tinggi. Selain itu adanya pertanaman atau perkebunan lain yang berada di dekat dengan suatu area pertanaman padi akan dapat meningkatkan 
Tabel 2. Parasitoid dan predator yang dominan ditemukan pada pertanaman kelapa sawit dan padi sawah

\begin{tabular}{|c|c|c|c|}
\hline Parasitoid & $\begin{array}{l}\text { Jumlah } \\
\text { Individu }\end{array}$ & Predator & $\begin{array}{l}\text { Jumlah } \\
\text { Individu }\end{array}$ \\
\hline $\begin{array}{l}\text { Telenomus podisi } \\
\text { (Hymenoptera: Scelionidae) }\end{array}$ & 462 & $\begin{array}{l}\text { Anoplolepis gracilipes (Hymenoptera: } \\
\text { Formicidae) }\end{array}$ & 1.201 \\
\hline $\begin{array}{l}\text { Anagrus optabilis (Hymenoptera: } \\
\text { Mymaridae) }\end{array}$ & 443 & $\begin{array}{l}\text { Forcipomyia sp. } 1 \\
\text { (Diptera: Ceratopogonidae) }\end{array}$ & 829 \\
\hline $\begin{array}{l}\text { Platygaster oryzae (Hymenoptera: } \\
\text { Platygastridae) }\end{array}$ & 344 & $\begin{array}{l}\text { Geocoris sp. } \\
\text { (Hemiptera: Lygaeidae) }\end{array}$ & 746 \\
\hline $\begin{array}{l}\text { Polypeza sp. } 1 \\
\text { (Hymenoptera: Diapriidae) }\end{array}$ & 292 & $\begin{array}{l}\text { Oxyopes sp. } \\
\text { (Araneaee: Oxyopidae) }\end{array}$ & 701 \\
\hline $\begin{array}{l}\text { Scelio sp. } \\
\text { (Hymenoptera: Scelionidae) }\end{array}$ & 292 & $\begin{array}{l}\text { Conocephalus longipennis } \\
\text { (Orthoptera: Tettigoniidae) }\end{array}$ & 621 \\
\hline
\end{tabular}

A

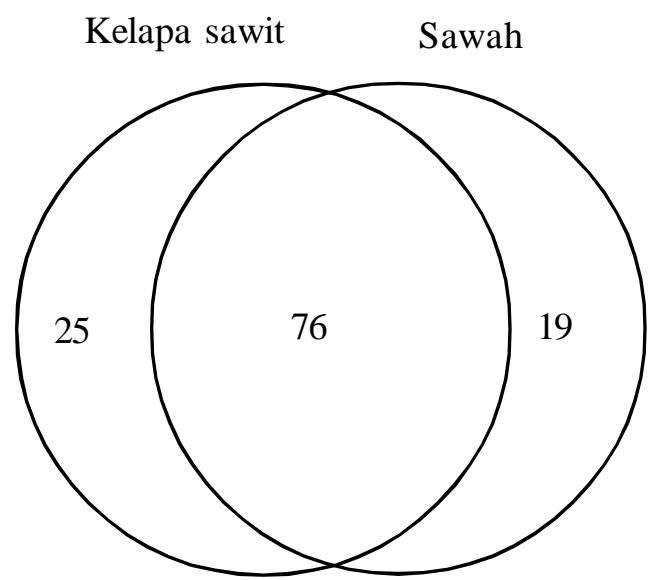

B Kelapa sawit

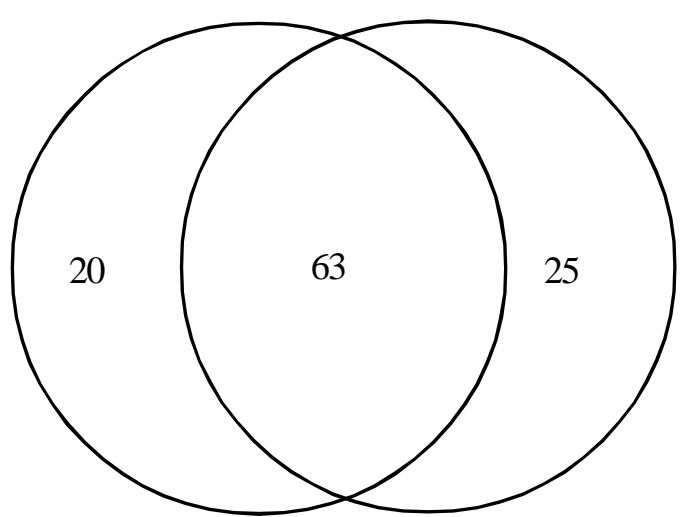

Gambar 2. Jumlah morfospesies (A) parasitoid dan (B) predator pada pertanaman kelapa sawit dan padi sawah

keanekaragaman yang terdapat di dalamnya (Janzen, 1987).

Vegetasi Bawah. Keanekaragaman serangga dipengaruhi oleh beberapa faktor, salah satunya adalah keanekaragaman vegetasi bawah. Vegetasi bawah yang ditemukan pada pertanaman kelapa sawit dan padi sawah ditemukan beragam (Tabel 3). Semakin beragam vegetasi bawah, maka semakin beragam pula keanekaragaman serangga pada habitat tersebut. Berdasarkan penelitian Hamid et al. (2003), apabila suatu habitat memiliki vegetasi yang lebih beranekaragam di dalamnya maka nilai keanekaragaman musuh alami yang berada pada habitat tersebut dapat meningkat. Keberadaan predator dan parasitoid pada vegetasi bawah berperan dalam pengendalian hama. Predator Cyrtorhinus sp. akan memangsa inang yang berada pada vegetasi bawah seperti Cynodon dactylon dan Leersia hexandra jika wereng batang coklat tidak ada pada pertanaman padi, serta menjadi tempat berkembang biak Cyrtorhinus sp., selain itu Leersia hexandra juga menjadi habitat bagi parasitoid Anagrus sp. (Kartohardjono, 2011).

\section{SIMPULAN}

Serangga parasitoid dan predator yang diperoleh pada pertanaman kelapa sawit berjumlah 184 morfospesies berasal dari 10 ordo dan 57 famili, sedangkan pada padi sawah diperoleh 183 morfospesies dari 10 ordo dan 60 famili. Parasitoid memiliki keanekaragaman dan kelimpahan tertinggi pada pertanaman kelapa sawit maupun padi sawah. Parasitoid Telenomus podisi dan predator Anoplolepis gracilipes merupakan morfospesies dengan kelimpahan tertinggi. Nilai indeks H' parasitoid dan predator yang didapat tergolong tinggi yaitu 3,49 yang berarti keanekaragaman spesies yang ditemukan tinggi pada kedua lokasi pertanaman. 
Tabel 3. Vegetasi bawah pada pertanaman kelapa sawit dan padi sawah

\begin{tabular}{|c|c|c|c|}
\hline \multirow{2}{*}{ Ordo } & \multirow{2}{*}{ Famili } & \multicolumn{2}{|c|}{ Lokasi (spesies) } \\
\hline & & Kelapa sawit & Sawah \\
\hline Alismatales & Alismataceae & & Limnocharis flava \\
\hline Apiales & Apiaceae & Centella asiatica & Centella asiatica \\
\hline Asterales & Asteraceae & $\begin{array}{l}\text { Ageratum conyzoides } \\
\text { Chromolaena odorata } \\
\text { Crassocephalum crepidioides } \\
\text { Sonchus arvensis }\end{array}$ & Ageratum conyzoides \\
\hline Brassicales & $\begin{array}{l}\text { Brassicaceae } \\
\text { Cleomaceae }\end{array}$ & Brassica juncea & Cleome rutidosperma \\
\hline Caryophyllales & $\begin{array}{l}\text { Polygonaceae } \\
\text { Amaranthaceae } \\
\text { Portulacaceae }\end{array}$ & $\begin{array}{l}\text { Polygonum barbatum } \\
\text { Amaranthus spinosus } \\
\text { Portulaca oleracea }\end{array}$ & Amaranthus sp. \\
\hline Commelinales & Pontederiaceae & & Monochoria hastata \\
\hline Dennstaedtiales & Dennstaedtiaceae & Pteridium aquilinum & \\
\hline Dicranales & Calymperaceae & Calymperes sp. & \\
\hline Fabales & Fabaceae & Mimosa pudica & Mimosa pudica \\
\hline Gentianales & Rubiaceae & Rubia cordifolia & \\
\hline Hypnales & Thuidiaceae & Thuidium sp. & \\
\hline Lamiales & Plantaginaceae & $\begin{array}{l}\text { Plantago major } \\
\text { Plantago lanceolata }\end{array}$ & $\begin{array}{l}\text { Plantago major } \\
\text { Plantago lanceolata }\end{array}$ \\
\hline & Lamiaceae & Mentha piperita & \\
\hline Malpighiales & $\begin{array}{l}\text { Phyllanthaceae } \\
\text { Euphorbiaceae }\end{array}$ & $\begin{array}{l}\text { Phyllanthus urinaria } \\
\text { Chamaesyce, Acalypha }\end{array}$ & Phyllanthus urinaria \\
\hline Myrtales & Onagraceae & & Ludwigia octovalvis \\
\hline & Melastomataceae & $\begin{array}{l}\text { Clidemia hirta } \\
\text { Melastoma malabathricum }\end{array}$ & Clidemia hirta \\
\hline Oxalidales & Oxalidaceae & Oxalis stricta & \\
\hline Piperales & Piperaceae & Peperomia pellucida & \\
\hline Poales & Poaceae & $\begin{array}{l}\text { Brachiaria humidicola } \\
\text { Brachiaria decumbens } \\
\text { Leptochloa chinensis } \\
\text { Leersia hexandra } \\
\text { Eleusine indica } \\
\text { Chrysopogon aciculatus } \\
\text { Panicum repens } \\
\text { Axonopus compressus } \\
\text { Cynodon dactylon }\end{array}$ & $\begin{array}{l}\text { Leptochloa chinensis } \\
\text { Leersia hexandra } \\
\text { Cynodon dactylon }\end{array}$ \\
\hline & Cyperaceae & $\begin{array}{l}\text { Cyperus longus } \\
\text { Cyperus rotundus } \\
\text { Kyllinga monocephala }\end{array}$ & $\begin{array}{l}\text { Cyperus longus } \\
\text { Cyperus rotundus } \\
\text { Kyllinga monocephala } \\
\text { Scleria sp. }\end{array}$ \\
\hline Polypodiales & Pteridaceae & $\begin{array}{l}\text { Adiantum sp. } \\
\text { Adiantum hispidulum } \\
\text { Adiantum tenerum }\end{array}$ & \\
\hline & Nephrolepidaceae & Nephrolepis biserrata & \\
\hline & Athyriaceae & Athyrium filix & \\
\hline Rosales & Urticaceae & Urtica dioica & \\
\hline Solanales & Convolvulaceae & Ipomoea indica & \\
\hline Salviniales & Marsileaceae & & Marsilea sp. \\
\hline
\end{tabular}




\section{SANWACANA}

Penelitian ini dibiayai oleh Direktorat Pendidikan Tinggi (Dikti) melalui Beasiswa Pendidikan Pascasarjana Dalam Negeri (BPPDN). Terima kasih kepada PTPN VIII Cindali Bogor yang telah memberikan izin penelitian sehingga saya dapat melakukan penelitian di lokasi perkebunan sawit tersebut.

\section{DAFTAR PUSTAKA}

Atkins MD. 1980. Introductions to Insect Behavior. MacMillan Publishing. New York.

Barbosa P \& Benrey B. 1998. The influence of plants on insect parasitoids: implications for conservation biological control. In: Barbosa P (Ed.). Conservation Biological Control. Pp: 39-54. Academic Press, San Diego (MX).

Borror DJ, Triplehorn CA, \& Johnson NF. 1996. Pengenalan Pelajaran Serangga Edisi ke-6. Partosoedjono S, penerjemah. Yogyakarta (ID): Gadjah Mada University Press. Terjemahan dari An Introduction to the Study of Insects.

Buchori D. 2014. Pengendalian hayati dan konservasi serangga untuk pembangunan Indonesia hijau. Orasi ilmiah guru besar IPB. Institut Pertanian Bogor. Bogor.

CSIRO [Commonwealth Scientific and Industrial Research Organization]. 1991. The Insects of Australia: A Textbook for Student and Research Worker. Melbourne University Press.

Daly HV, Doyen JT, \& Ehrlich PR. 1978. Introduction to Insect Biology and Diversity. International Student Edition. Mc Graw Hill. Tokyo.

Godfray HCJ. 1994. Parasitoid: Behavioral and Evolutionary Ecology. Pricenton University Press, New Jersey.

Goulet H \& Huber JT. 1993. Hymenoptera of the World: An Identification Guide to Families. Minister of Supply and Services Canada, Ottawa.

Grissell EE \& Schauff ME. 1990. A Handbook of the Families of Nearctic Chalcidoidea (Hymenoptera). Washington (US): The Entomological Society of Washington.
Hamid H, Buchori D, \& Triwidodo H. 2003. Keanekaragaman parasitoid dan parasitisasinya pada pertanaman padi di kawasan Taman Nasional Gunung Halimun. Hayati 10(3): 85-90.

Hassel MP \& Waage JK. 1984. Host-parasitoid population interactions. Ann. Rev. Entomol. 29: $89-114$.

Herlinda S, Waluyo, Estuningsih SP, \& Irsan C. 2008. Perbandingan keanekaragaman spesies dan kelimpahan Arthropoda predator penghuni tanah di sawah lebak yang diaplikasi dan tanpa aplikasi insektisida. J. Entomol. Indones. 5(2): 96-107.

Janzen DH. 1987. Insect diversity of a Costa Rican dry forest: why keep it, and how? Biol J. Linn. Soc. 30(4): 343-356.

Kartohardjono A. 2011. Penggunaan musuh alami sebagai komponen pengendalian hama padi berbasis ekologi. Pengem. Inov. Pert. 4(1): 2946.

LaSalle J. 1993. Parasitic Hymenoptera, biological control and biodiversity. In: LaSalle J \& Gauld ID (Eds.) Hymenoptera and Biodiversity. CAB International Oxon, Wallingford.

Luskin MS \& Potts MD. 2011. Microclimate and habitat heterogeneity through the oil palm life cycle. Basic Appl Ecol. 12(6): 540-551.

Nolan KA \& Callahan JE. 2006. Beachcomber biology: the Shannon-Wiener species diversity index. ABLE. 27: 334-338.

Pradhana RAI, Mudjiono G, \& Karindah S. 2014. Keanekaragaman serangga dan laba-laba pada pertanaman padi organic dan konvensional. $J$. HPT Tropika. 2(2): 58-64.

Rizali A, Buchori D, \& Triwidodo H. 2002. Keanekaragaman serangga pada lahan persawahan-tepian hutan indikator untuk kesehatan lingkungan. Hayati 9: 41-48.

Rohrig E, Sitvinski J, \& Wharton R. 2008. Comparison of parasitic Hymenoptera captured in malaise traps baited with two flowering plants, Lobularia maritima (Brassicales: Brassicaceae) and Spermacoce verticilata (Gentianales: Rubiaceae). Fla Entomol. 91(4): 621-627. 
Sahari B. 2012. Struktur komunitas parasitoid Hymenoptera di perkebunan kelapa sawit, Desa Pandu Senjaya, Kecamatan Pangkalan Lada, Kalimantan Tengah [disertasi]. Institut Pertanian Bogor. Bogor.

Siemann E, Haarstad J, \& Tilman D. 1999. Dynamics of plant and arthropod diversity during old field succession. Ecography 22: 406-414.
Triplehorn CA \& Johnson NF. 2005. Borror and DeLong's Introduction to the Study of Insect 7th Edition. Cengage Learning, Stamford (US).

Yaherwandi. 2005. Keanekaragaman Hymenoptera parasitoid pada beberapa tipe lanskap pertanian di Daerah Aliran Sungai (DAS) Cianjur Kabupaten Cianjur, Jawa Barat [disertasi]. Institut Pertanian Bogor, Bogor. 